\section{OPEN ACCESS}

Edited by:

Joseph Sullivan,

UCSF Benioff Children's Hospital,

United States

Reviewed by:

Maurizio Elia,

IRCCS Oasi Maria SS, Italy

Mario Mastrange/o,

Umberto 1 Polyclinic, Italy

*Correspondence:

Giovanni Battista Dell'Isola giovanni.dellisola@gmail.com

$$
\begin{array}{r}
\text { Specialty section: } \\
\text { This article was submitted to } \\
\text { Pediatric Neurology, } \\
\text { a section of the journal } \\
\text { Frontiers in Neurology }
\end{array}
$$

Received: 20 September 2021 Accepted: 15 December 2021

Published: 17 January 2022

Citation:

Dell'Isola GB, Vinti V, Fattorusso $A$ Tascini G, Mencaroni E, Di Cara G, Striano $P$ and Verrotti A (2022) The Broad Clinical Spectrum of Epilepsies Associated With Protocadherin 19 Gene Mutation.

Front. Neurol. 12:780053. doi: 10.3389/fneur.2021.780053

\title{
The Broad Clinical Spectrum of Epilepsies Associated With Protocadherin 19 Gene Mutation
}

\section{Giovanni Battista Dell'Isola ${ }^{1 *}$, Valerio Vinti ${ }^{1}$, Antonella Fattorusso ${ }^{1}$, Giorgia Tascini ${ }^{1}$, Elisabetta Mencaroni ${ }^{1}$, Giuseppe Di Cara ${ }^{1}$, Pasquale Striano ${ }^{2,3}$ and Alberto Verrotti ${ }^{1}$}

${ }^{1}$ Department of Pediatrics, University of Perugia, Perugia, Italy, ${ }^{2}$ Pediatric Neurology and Muscular Diseases Unit, Istituto di Ricovero e Cura a Carattere Scientifico (IRCCS) "G. Gaslini" Institute, Genoa, Italy, ${ }^{3}$ Department of Neurosciences,

Rehabilitation, Ophthalmology, Genetics, Maternal and Child Health, University of Genoa, Genoa, Italy

Protocadherin 19 (PCDH19) gene is one of the most common genes involved in epilepsy syndromes. According to literature data PCDH19 is among the 6 genes most involved in genetic epilepsies. PCDH19 is located on chromosome Xq22.1 and is involved in neuronal connections and signal transduction. The most frequent clinical expression of PCDH19 mutation is epilepsy and mental retardation limited to female (EFMR) characterized by epileptic and non-epileptic symptoms affecting mainly females. However, the phenotypic spectrum of these mutations is considerably variable from genetic epilepsy with febrile seizure plus to epileptic encephalopathies. The peculiar exclusive involvement of females seems to be caused by a cellular interference in heterozygosity, however, affected mosaic-males have been reported. Seizure types range from focal seizure to generalized tonic-clonic, tonic, atonic, absences, and myoclonic jerks. Treatment of PCDH19-related epilepsy is limited by drug resistance and by the absence of specific treatment indications. However, seizures become less severe with adolescence and some patients may even become seizure-free. Non-epileptic symptoms represent the main disabilities of adult patients with $\mathrm{PCDH} 19$ mutation. This review aims to analyze the highly variable phenotypic expression of PCDH19 gene mutation associated with epilepsy.

Keywords: PCDH19, epilepsy and mental retardation limited to female (EFMR), GEFS, Dravet syndrome, antiseizure medication (ASM)

\section{INTRODUCTION}

The latest ILAE classification (1) emphasizes the importance of an etiological classification of epilepsy to improve prognosis and, whether possible, initiate a target therapy. In fact, besides allowing a stratification of risk based on the genotype-phenotype correlation, different patterns of gene mutations could present specific drug-response and lead to target therapy. The main genes associated with epilepsy can be classified based on five different functions: (I) ion transport; (II) cell growth and differentiation; (III) synaptic processes regulation; (IV) transport and metabolism within and between cells of small molecules; and (V) gene transcription and translation (2). One of the most commonly implicated genes in epilepsy is the protocadherin 19 (PCDH19) gene located on chromosome Xq22.1. According to Symonds et al. (2) PCDH19 is among the six genes most involved in genetic epilepsies (Figure 1). 


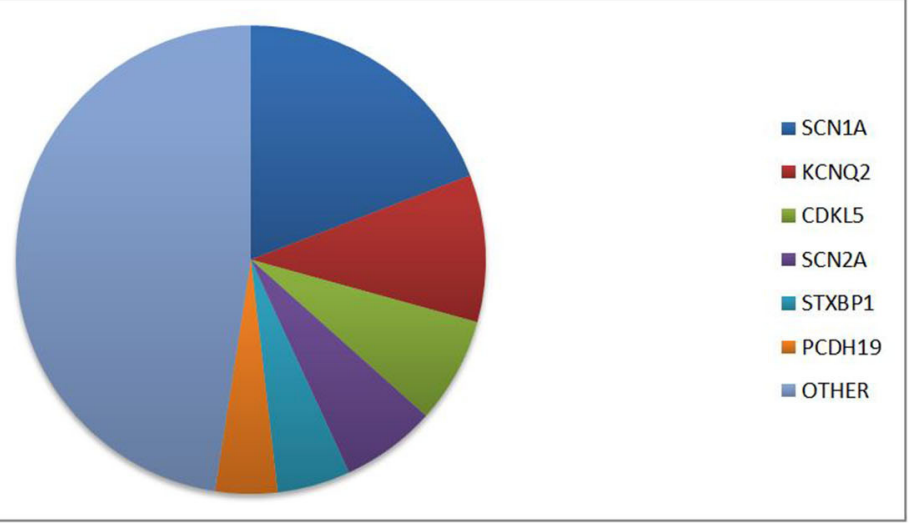

FIGURE 1 | Prevalence of different gene mutations in genetic epilepsies according to literature data [data from (2)].

PCDH19 gene is expressed in several organs, but primarily in the limbic areas of the nervous system (3). It has a six-exon structure that encodes a transmembrane adhesion molecule of the Cadherin family. The Cadherin superfamily comprises three subgroups of transmembrane cell adhesion molecules: cadherins, protocadherins, and desmosomal cadherins (4). Among these protocadherins represent the main subgroup with approximately 80 members involved in neuronal connections and signal transduction $(5,6)$. Almost 150 PCDH19 mutations have been described as either familiar clustering or de novo (7). Most mutations involve the extracellular protein domains encoded by exon 1 and are typically missense variations $(7,8)$. However, a few mutations of intracellular domains have also been reported, possibly affecting the intracellular signal pathway. Proper development of neural architecture and neuronal connectivity require efficacious cell-cell interactions and alterations of protocadherins could result in severe disruption in early brain morphogenesis. It is not well known how mutations of PCDH19 lead to the development of epilepsy. However, a role of this gene in the proliferation of neuronal progenitors and the regulation of cell motility during the early stages of neurulation has been proposed $(9,10)$. Recent in vitro studies, conducted with patientderived induced pluripotent stem cells showed an accelerated differentiation in cells with PCDH19 mutation. It is also observed that increased neurogenesis occurs earlier in PCDH19-mutated culture with an increased neurite length and occurrence of premature neural rosettes. Accelerated neurogenesis is involved with a defect in the cell division plane at the stage of the neural progenitors. Moreover, it is possible that PCDH19 mutations can alter the correct positioning of the mitotic spindle causing a higher number of asymmetric divisions leading to accelerating neural differentiation. An altered equilibrium between symmetric vs. asymmetric cell division may contribute to the pathogenesis of the disease (11). The synaptogenesis role of PCDH19 was confirmed by Mincheva-Tasheva et al. who showed disruption of excitatory synaptic contacts between PCDH19knock-out and wild-type neurons in "mosaic" neuronal cultures (12). In addition, PCDH19 mutation leads to a decrease in $\mathrm{N}$-cadherin-dependent signaling resulting in an impaired mossy fiber synapse development (13). The interaction between the cytoplasmic domains of PCDH19 with the alpha subunits of the GABAa receptor could alter the excitatory-inhibitory balance underlying epilepsy (14). Besides regulating GABAa receptor surface expression, PCDH19 also regulates channel gating. Indeed, PCDH19-mutated cortical neurons have a spontaneous $\mathrm{Ca}^{2+}$ intracellular flux suggesting increase excitability of these cells (15). Another theory suggests PCDH19 involvement in blood-brain barrier (BBB) dysfunction. In fact, the gene is highly expressed in endothelial cells and the main epileptic foci involve the limbic region, close to the periventricular region where BBB is missing. Furthermore, this theory could explain the seizure remission with growth thanks to the maturation of BBB (16). The phenotypic spectrum of PCHD19 mutation is extremely variable involving neurological and psychiatric diseases. Although epilepsy and mental retardation limited to female (EFMR) is the most frequent clinical expression of PCDH19 mutation, other important clinical manifestations are genetic epilepsy with febrile seizure plus (GEFS+) and epileptic encephalopathies. This review aims to analyze the phenotypic expression of PCDH19 gene mutation associated with epilepsy.

\section{LITERATURE SEARCH}

We reviewed the papers (English language only) on PCDH19related epilepsy through a Literature search on PubMed until August 2021. The terms "PCDH19" and "PCDH19" epilepsy were used in this systematic search. We included case reports and open-label studies. Moreover, we searched for additional articles through a review of the reference lists of published reviews.

\section{EPILEPSY AND MENTAL RETARDATION LIMITED TO FEMALE}

Epilepsy and mental retardation limited to female (EFMR) was first described by Juberg and Hellman (17) in 15 related females presenting epilepsy with cognitive impairment. This clinical manifestation was only later related to mutations of 
the PCDH19 gene $(8,18)$. Brain MRI is generally normal and there are no peculiar electroencephalographic (EEG) features of PCDH19 mutation. Figure 2 shows an EEG of a female patient with PCDH19 mutation and focal epilepsy. The phenotypic expression of EFMR is characterized by epileptic and nonepileptic symptoms. The hallmark feature especially in the early stages of the disease is cluster focal seizures with the tendency to prolonged episodes poorly responsive to antiepileptic therapy (19). The patient often displays early-onset seizures (6-36 months) generally sensitive to fever (20). Seizure types range from focal seizure to generalized tonic-clonic, tonic, atonic, absences, and myoclonic jerks. The severity of epilepsy is also extremely variable from drug-resistant and progressive forms to self-limiting ones. Seizures become less severe with adolescence while non-epileptic symptoms represent the main disabilities of adult patients with PCDH19 mutation (21). Non-epileptic features of EFMR include intellectual disability (ID) and behavior disturbances occurring in 75.4 and $55.4 \%$ of patients, respectively (21). In a study of 195 patients with PCDH19 mutations, only 28.2\% had normal cognitive development, while patients with mild, moderate, and severe impairment were 27.2, 22.2, and $17.4 \%$, respectively (7). A delay in the acquisition of language milestones represents a common feature of all patients and the absence of language before seizure onset represents a possible negative prognostic factor for cognitive development (22). Although most patients manifest cognitive delay after 2 years of age, $15 \%$ of cases present intellectual disabilities before the onset of epilepsy. Therefore, intellectual impairment is only partially related to epileptic encephalopathy and other genetic and/or environmental factors are among the causes of the phenotypic spectrum. The peculiar exclusive involvement of females seems to be caused by a cellular interference in heterozygosity. According to this theory, the coexistence of mutated cells with wild-type cells causes the neural network alteration at the base of the disease $(17,23)$. Confirming this hypothesis, while hemizygotic males are asymptomatic carriers, affected mosaic-males have been reported (24). Indeed, postzygotic somatic variants in males would configure a picture overlapping with that of females in heterozygosity. A mutation penetrance of $\sim 80 \%$ was estimated for both conditions $(7,25)$. The small number of affected males makes difficult a phenotypic characterization of these patients. The phenotypic spectrum of mosaic-males resembles that of affected females. In addition, psychiatric comorbidity has also been described in two males with germline mutation, albeit the possible correlation with the mutation is questionable (25). Several studies have looked for a genotype-phenotype correlation without any result. According to a recent study, missense variants seem to be more commonly related to normal cognitive development compared to the loss of function mutations (26). Whole gene deletion appears as well associated with a worsened prognosis. According to Shibata et al. truncating variants located from extracellular domain 5 (EC5) to the cytoplasmic domain present a later seizure onset with less severe intellectual disability compared to missense variants and truncating variants from EC1 to EC4 (27). Cognitive impairment does not appear to be directly associated with seizure severity (22). To date, age at seizure onset and seizure frequency are the only unfavorable prognostic factors associated with cognitive function $(7,26)$.
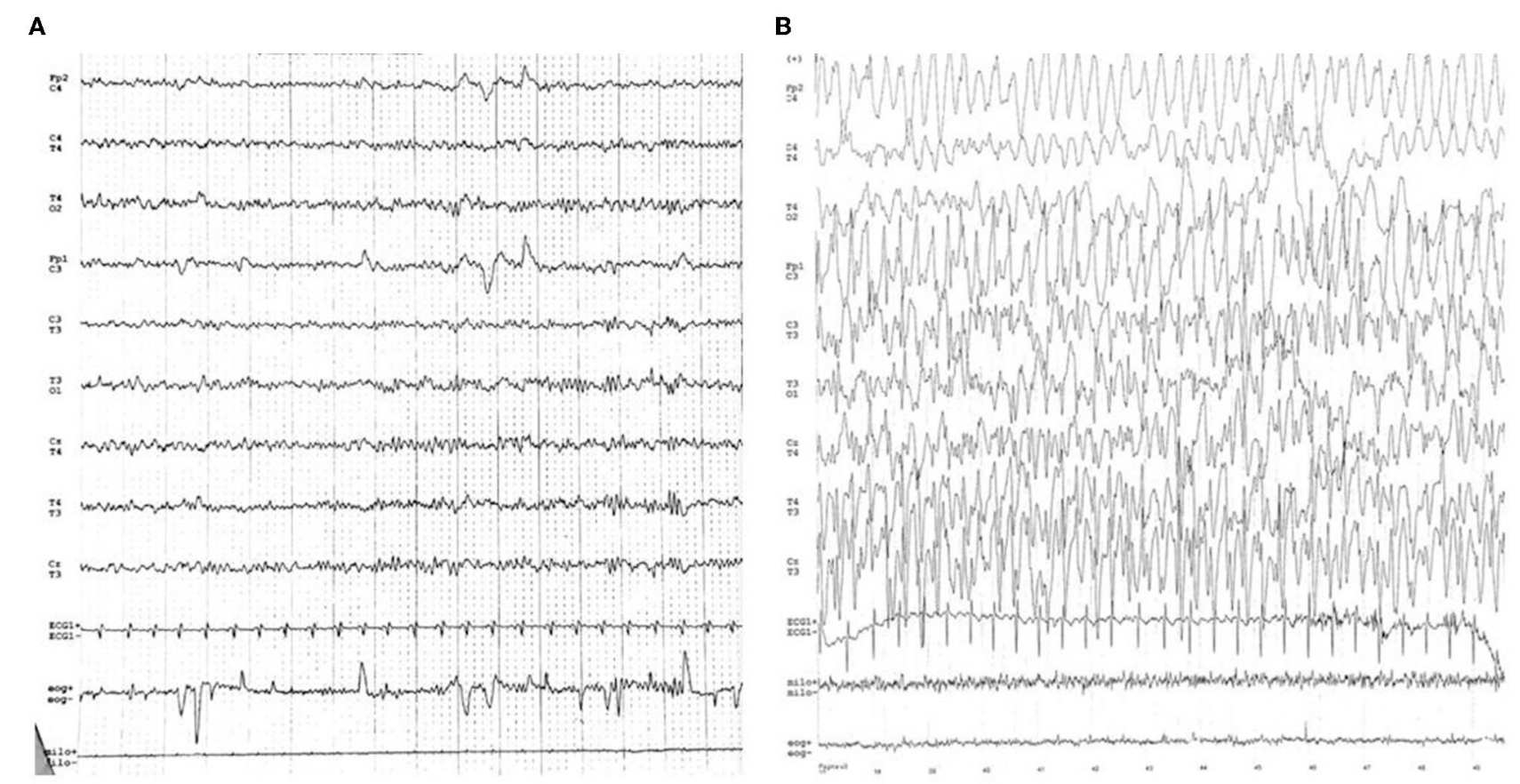

FIGURE 2 | (A) Normal inter-ictal EEG. (B) Ictal-EEG characterized by frontal theta activity of the left hemisphere followed by sharp waves on the same derivations. Slow waves spread on the frontal derivations of the right hemisphere, followed by diffuse slow waves (except on the right posterior deviations). 
Indeed, the occurrence of new synapses' processing and changes in the frontal cortex predominantly in the first years of life may justify this correlation (7). In addition, the epileptic expression, also the neuropsychiatric profile is extremely heterogeneous, ranging from mild to severe forms with combination of autistic, attention-deficit/hyperactive, obsessive, or aggressive features (28). Approximately $25 \%$ of patients without intellectual disability presents psychiatric comorbidity (7). In addition, there is data that sleep alterations is a common feature in patients with EFMR. Both difficulty in maintaining sleep and in absorption have been reported (28). A more complete analysis of these disorders could be useful especially in light of the correlation between sleep disturbances and worse control of epileptic symptoms. The wide variability in the phenotypic expression of EFMR could be partially explained by X-inactivation in females. However, further studies are needed for a greater knowledge of the impaired biological processes in EFMR and to investigate possible genotype-phenotype correlations.

\section{GENETIC EPILEPSY WITH FEBRILE SEIZURES PLUS}

Febrile seizures (FS) are the most common clinical presentation of GEFS+, followed by febrile seizures plus (FS+). However, absence, myoclonic, atonic, or focal seizures combined with the most frequent phenotypes are also common. Confirming the various spectrum of this disorder, epileptic encephalopathy like Dravet syndrome (DS) and epilepsy with myoclonic-atonic seizures (MAE) are possible manifestations in GEFS+ families. The clinical presentation of PCDH19-related epilepsy often overlaps with that of GEFS + . In both, focal seizures with variable degrees of intellectual disabilities can be part of the phenotypic spectrum. To define a GEFS + family are necessary two or more individuals with GEFS + phenotypes including at least one with FS or FS+ (29-31). GEFS + was initially described as a genetic disorder following an autosomal dominant pattern of inheritance with incomplete penetrance $(29,32,33)$. However, some sporadic cases suggested that de novo mutation or polygenic pattern could also cause the disease $(31,33-36)$. With a better knowledge of the clinical presentation, it is now possible to recognize GEFS+ even outside a family context when de novo mutations in the GEFS+ gene are found (36). Several genes mutations are described underlying GEFS+ (37-48) including PCDH19 $(49,50)$. SCN1A is the most commonly involved gene, whose mutations are identified in $19 \%$ of affected families $(30,37)$. There is a known similarity between the phenotypic spectrum of PCDH19 and SCN1A, which includes DS and extends to GEFS+. Recognizing PCDH19 mutations in the context of a GEFS+ presentation can be difficult. However, seizure clusters prevalent in the females should point toward the search for PCDH19 mutations.

\section{DRAVET-LIKE SYNDROME}

Dravet syndrome (DS), originally named "severe myoclonic epilepsy of infancy," represents one of the most severe genetic epilepsy with childhood onset. According to the ILAE classification, the typical DS is defined by febrile and afebrile seizures that occur in the first year of life in an infant with normal development and the subsequent appearance of myoclonus, atypical absences, and focal seizures. Seizures become drugresistant leading to poor prognosis with motor, cognitive, and psychiatric impairment of affected patients $(1,51)$. SCN1A is the most frequently involved gene occurring in $70-80 \%$ of DS $(52,53)$. DS-like phenotype is a similar condition due to the occurrence of other gene mutations involved in encephalopathy. In a recent study, mutations in the PCDH19 gene appear to be the underlying cause of DS-like phenotype in $16 \%$ of DS negative for SCN1A mutations (54). The variants in the SCN1A and PCDH19 genes show some similarities that link DS to DS-like, but they differ from each other for some peculiarities (55). Due to the unusual X-linked inheritance of PCDH19 gene mutations, DS-like is more common in females. The onset of symptoms is earlier in DS than in DS-like, with an average range of 36 and 8-54 months, respectively $(56,57)$. Fever represents the main triggering seizure factor for both DS and DS-like, however PCDH19 mutations show fewer provocation factors for seizure initiation (55). Clonic and hemiclonic seizures are mainly related to SCN1A mutations that also present a higher prevalence of generalized tonic-clonic seizures and atypical absences with more common status epilepticus. Whereas, seizure types associated with PCDH19 variants are often focal and hypomotor seizures with a higher prevalence of cluster seizures (57). Seizures with affective symptoms and fearful screaming have been described by many authors as a characteristic feature of DS-like (19). DSlike phenotype is less associated with photosensitivity compared to DS. Another relevant difference is the interval for the second seizure occurrence: 10 months for DS-like vs. 2-3 months for DS, probably due to the higher frequency of seizures in the first year of life and the earliest onset in DS patients $(20,57)$. Interictal EEG may have no abnormalities, however focal or generalized slow wave, sharp and polyspike discharges have been reported (22). DS-like phenotype carrying the PCDH19 pathogenic variants has greater variability in cognitive disability including some cases without intellectual impairment $(20,22,57)$. In contrast, patients with DS present a greater degree of cognitive impairment, regardless of variant significance (55). Autism predominantly involves DS-like, occurring in $62.5 \%$ of patients with PCDH19 mutations vs. $37.5 \%$ of patients with SCN1A mutations (55).

\section{TREATMENT OF PCDH19-RELATED EPILEPSY}

Treatment of PCDH19-related epilepsy is limited by drug resistance and by the absence of specific treatment indications. These patients usually need polytherapy frequently with poor efficacy due to the natural fluctuating trend of seizures and to the various cluster triggers. The management of drugrefractory patients represents a great challenge for physicians, especially for syndromes with heterogeneous seizure semeiology and course (58). Currently, different drug associations have been tested and none has definitively proven to be superior (Table 1). However, familiar mutations show the same reactivity 
TABLE 1 | Clinical, EEG and MRI characteristics and treatment efficacy in PCDH19-related epilepsy.

\begin{tabular}{|c|c|c|c|c|c|c|c|c|}
\hline References & $\begin{array}{l}\text { Sample } \\
\text { size }\end{array}$ & $\begin{array}{l}\text { Mean age at } \\
\text { seizure } \\
\text { onset }\end{array}$ & Seizure semiology & EEG patterns & Comorbidities & MRI findings & Treatments & Treatments efficacy \\
\hline $\begin{array}{l}\text { Scheffer et al. } \\
\text { (18) }\end{array}$ & 27 & 14 months & $\begin{array}{l}\text { Tonic, tonic-clonic, partial, } \\
\text { absence, atonic and } \\
\text { myoclonic }\end{array}$ & $\begin{array}{l}\text { Generalized spike wave and } \\
\text { polyspike wave, focal } \\
\text { discharges with more } \\
\text { frequent frontotemporal } \\
\text { involvement }\end{array}$ & $\begin{array}{l}\text { ID (15/27) Autistic traits } \\
(6 / 13) \text { Obsessive features } \\
(9 / 27) \text { Aggressive behavior } \\
(7 / 27)\end{array}$ & n.a. & $\begin{array}{l}\text { VPA, LTG, PHT, } \\
\text { PB, }\end{array}$ & n.a. \\
\hline $\begin{array}{l}\text { Depienne et } \\
\text { al. (24) }\end{array}$ & 13 & 9.5 months & $\begin{array}{l}\text { Febrile and afebrile seizure, } \\
\text { GTCS, absences, partial } \\
\text { and hemiclonic }\end{array}$ & n.a. & $\begin{array}{l}\text { ID }(13 / 13) \text { Behavioral } \\
\text { disturbances }(5 / 13) \text { Autistic } \\
\text { features }(2 / 13)\end{array}$ & n.a. & $\begin{array}{l}\text { VPA, CLZ, CLB, } \\
\text { TPM, STP, LTG }\end{array}$ & n.a. \\
\hline $\begin{array}{l}\text { Marini et al. } \\
\text { (59) }\end{array}$ & 13 & 8.5 months & $\begin{array}{l}\text { Tonic-clonic, absences, } \\
\text { myoclonic and focal }\end{array}$ & $\begin{array}{l}\text { Centroparietooccipital } \\
\text { activity }(5 / 13) \text { and } \\
\text { frontotemporal activity } \\
(2 / 13)\end{array}$ & $\begin{array}{l}\text { ID (11/13) Autistic features } \\
(5 / 13)\end{array}$ & Normal (13/13) & n.a. & n.a. \\
\hline $\begin{array}{l}\text { Depienne et } \\
\text { al. (20) }\end{array}$ & 25 & 2-54 months & $\begin{array}{l}\text { GTCS, tonic, focal, } \\
\text { hemiclonic, absence, } \\
\text { myoclonic }\end{array}$ & $\begin{array}{l}\text { Normal, focal and } \\
\text { generalized seizures }\end{array}$ & $\begin{array}{l}\text { ID (18/25), Behavioral } \\
\text { disturbances (7/25) }\end{array}$ & $\begin{array}{l}\text { Normal, frontal } \\
\text { median dermoid } \\
\text { cyst }(1 / 25)\end{array}$ & $\begin{array}{l}\text { TPM, LEV, ZNS, } \\
\text { CBZ, PB, VPA, } \\
\text { LTG, PB, VGB, } \\
\text { PHT, STP, CLN, } \\
\text { CLB, NTZ }\end{array}$ & $\begin{array}{l}\text { Seizures appeared highly } \\
\text { resistant to ASM during the } \\
\text { first years of life, the } \\
\text { frequency and } \\
\text { pharmacoresistance of } \\
\text { seizures tended to decrease } \\
\text { over time. The only drugs } \\
\text { reporting a negative effect } \\
\text { were CBZ, LTG and VGB }\end{array}$ \\
\hline $\begin{array}{l}\text { Marini et al. } \\
\text { (19) }\end{array}$ & 35 & 10 months & $\begin{array}{l}\text { Clusters of focal febrile or } \\
\text { afebrile seizures. Fearful } \\
\text { screaming (24/35) }\end{array}$ & $\begin{array}{l}\text { Prominent involvement of } \\
\text { the frontotemporal regions } \\
(22 / 35)\end{array}$ & $\begin{array}{l}\text { ID (24/35) Autistic traits } \\
(11 / 35)\end{array}$ & Normal (35/35) & $\begin{array}{l}\text { GVG, OxCZ, LTG, } \\
\text { LEV, VPA, PB, } \\
\text { TPM, LCM, CZP, } \\
\text { ESM, CLB, PHT, } \\
\text { CLP, PGB, NZP, } \\
\text { DZP }\end{array}$ & $\begin{array}{l}\text { No specific drug or } \\
\text { combination of drugs } \\
\text { appeared to have been } \\
\text { more effective than others. } \\
\text { Oral, rectal, or intravenous } \\
\text { benzodiazepines had been } \\
\text { successful in arresting } \\
\text { seizure clusters }\end{array}$ \\
\hline $\begin{array}{l}\text { Higurashi et } \\
\text { al. (60) }\end{array}$ & 18 & 8.6 months & $\begin{array}{l}\text { Tonic, tonic-clonic and focal } \\
\text { seizures often with } \\
\text { subsequent generalization }\end{array}$ & $\begin{array}{l}\text { Frontal and/or temporal } \\
\text { activities }(9 / 18) \text {, occipital } \\
\text { involvement (4/18) }\end{array}$ & $\begin{array}{l}\text { ID (15/18) Autistic traits } \\
(13 / 18)\end{array}$ & $\begin{array}{l}\text { Normal (13/18), } \\
\text { Frontal heterotopia } \\
\text { (1/18), Occipital } \\
\text { atrophy (1/18), } \\
\text { Hippocampal } \\
\text { atrophy (1/18), } \\
\text { White matter } \\
\text { lesion (1/18) }\end{array}$ & $\begin{array}{l}\text { PHT, BR, CLB, } \\
\text { TPM, VPA, CZP, } \\
\text { ZNS, PB, CBZ }\end{array}$ & $\begin{array}{l}\text { MDZ showed efficacy in } \\
\text { suppressing the ongoing } \\
\text { seizure, but was insufficient } \\
\text { to manage strong clusters. } \\
\text { PHT, BR and CLB were } \\
\text { beneficial for decreasing } \\
\text { Seizures. CBZ had the } \\
\text { poorest efficacy }\end{array}$ \\
\hline $\begin{array}{l}\text { Harssel et al. } \\
\text { (61) }\end{array}$ & 15 & 4-17 months & $\begin{array}{l}\text { Tonic-clonic, tonic, } \\
\text { hemiclonic, myoclonic, focal }\end{array}$ & $\begin{array}{l}\text { Focal, multifocal or bilateral } \\
\text { synchronous discharges, } \\
\text { and background activity } \\
\text { was either normal or } \\
\text { showed slowing }\end{array}$ & $\begin{array}{l}\text { ID (13/15) Behavioral } \\
\text { disturbances (11/15) } \\
\text { Autistic trait }(6 / 15)\end{array}$ & $\begin{array}{l}\text { Normal (14/15), } \\
\text { slight asymmetry } \\
\text { frontal lobes (1/15) }\end{array}$ & n.a & n.a \\
\hline
\end{tabular}


TABLE 1 | Continued

\begin{tabular}{|c|c|c|c|c|c|c|c|c|}
\hline References & $\begin{array}{l}\text { Sample } \\
\text { size }\end{array}$ & $\begin{array}{l}\text { Mean age at } \\
\text { seizure } \\
\text { onset }\end{array}$ & Seizure semiology & EEG patterns & Comorbidities & MRI findings & Treatments & Treatments efficacy \\
\hline Liu et al. (62) & 21 & 5-18 months & GTCS, focal, myoclonic & $\begin{array}{l}\text { Focal or multifocal seizures } \\
\text { from the } \\
\text { centroparieto-occipital } \\
\text { regions or temporal region } \\
(5 / 21) \text {. Interictal focal or } \\
\text { multifocal epileptic } \\
\text { discharges in the } \\
\text { centroparietooccipital or } \\
\text { frontotemporal regions } \\
(14 / 21)\end{array}$ & ID (17/21) Autistic trait (3/21) & Normal (21/21) & $\begin{array}{l}\text { PB, LTG, LEV, } \\
\text { VPA, TPM, CBZ, } \\
\text { TPM, OXC, NZP }\end{array}$ & $\begin{array}{l}\text { Seizures were refractory to } \\
\text { antiepileptic drugs at onset } \\
\text { in all patients. Seizure } \\
\text { frequency and intractability } \\
\text { tended to decrease over } \\
\text { time }\end{array}$ \\
\hline $\begin{array}{l}\text { Lotte et al. } \\
\text { (63) }\end{array}$ & 58 & 11.2 months & GTCS (81\%) & n.a. & $\begin{array}{l}\text { Motor impairment }(25 / 58) \text { ID } \\
(48 / 58) \text { Behavioral disorders } \\
(39 / 58)\end{array}$ & $\begin{array}{l}\text { Normal }(38 / 58) \text {, } \\
\text { focal cortical } \\
\text { dysplasia }(2 / 58)\end{array}$ & $\begin{array}{l}\text { BR, CBZ, CLB, } \\
\text { CZP, ESM, GBP, } \\
\text { CM,LEV, LTG, LZP, } \\
\text { NZP, OXC, PB, } \\
\text { PER, PGB, PHT, } \\
\text { RFN,STM, STP, } \\
\text { TPM, VGB, VPA, } \\
\text { ZNS }\end{array}$ & $\begin{array}{l}\text { CLB and BR decreased } \\
\text { seizure frequency by more } \\
\text { than } 50 \% \text { with a responder } \\
\text { rate of } 68 \text { and } 67 \% \text {, } \\
\text { respectively. A long-term } \\
\text { response of } 50 \text { and } 43 \% \\
\text { respectively was detected } \\
\text { after } 12 \text { months. PHT } \\
\text { resulted particularly } \\
\text { ineffective. }\end{array}$ \\
\hline $\begin{array}{l}\text { Chemaly et al. } \\
\text { (56) }\end{array}$ & 13 & 4-14 months & $\begin{array}{l}\text { GTCS, focal, atypical } \\
\text { absence }\end{array}$ & $\begin{array}{l}\text { temporo-occipital and } \\
\text { frontal onset }(8 / 13)\end{array}$ & $\begin{array}{l}\text { ID (12/13) Autistic traits } \\
(9 / 13)\end{array}$ & Normal (13/13) & $\begin{array}{l}\text { VPA,CLZ,VGB, } \\
\text { LEV,CLB, PB, } \\
\text { STP,TPM, CZP, } \\
\text { CBZ, LTG, PHT, } \\
\text { LVT, ETX }\end{array}$ & $\begin{array}{l}\text { Clusters responded to } \\
\text { benzodiazepines. STP } \\
\text { decreased seizure } \\
\text { frequency by more than } \\
50 \% \text {. VGB had a negative } \\
\text { impact on behavior in two } \\
\text { patients with seizure } \\
\text { worsening and was } \\
\text { stopped. }\end{array}$ \\
\hline $\begin{array}{l}\text { Smith et al. } \\
\text { (26) }\end{array}$ & 38 & 11.8 months & Focal, generalized seizures & n.a. & $\begin{array}{l}\text { ID (30/38) Behavioral } \\
\text { abnormalities (29/38) } \\
\text { Autistic features (22/38) } \\
\text { Abnormal sleeping patterns } \\
(20 / 25)\end{array}$ & Normal & $\begin{array}{l}\text { Most frequently } \\
\text { used medications } \\
\text { include BZP, OXC, } \\
\text { VPA, LEV }\end{array}$ & $\begin{array}{l}\text { Uncontrolled seizures with } \\
\text { more than } 3 \text { medications } \\
(23 / 38) \text {, uncontrolled } \\
\text { seizures with less than } 3 \\
\text { medications ( } 7 / 38) \text {, } \\
\text { Controlled seizures with } \\
\text { more than } 3 \text { medication } \\
\text { (5/38), Controlled seizures } \\
\text { with less than } 3 \text { medication } \\
\text { (3/38) }\end{array}$ \\
\hline
\end{tabular}




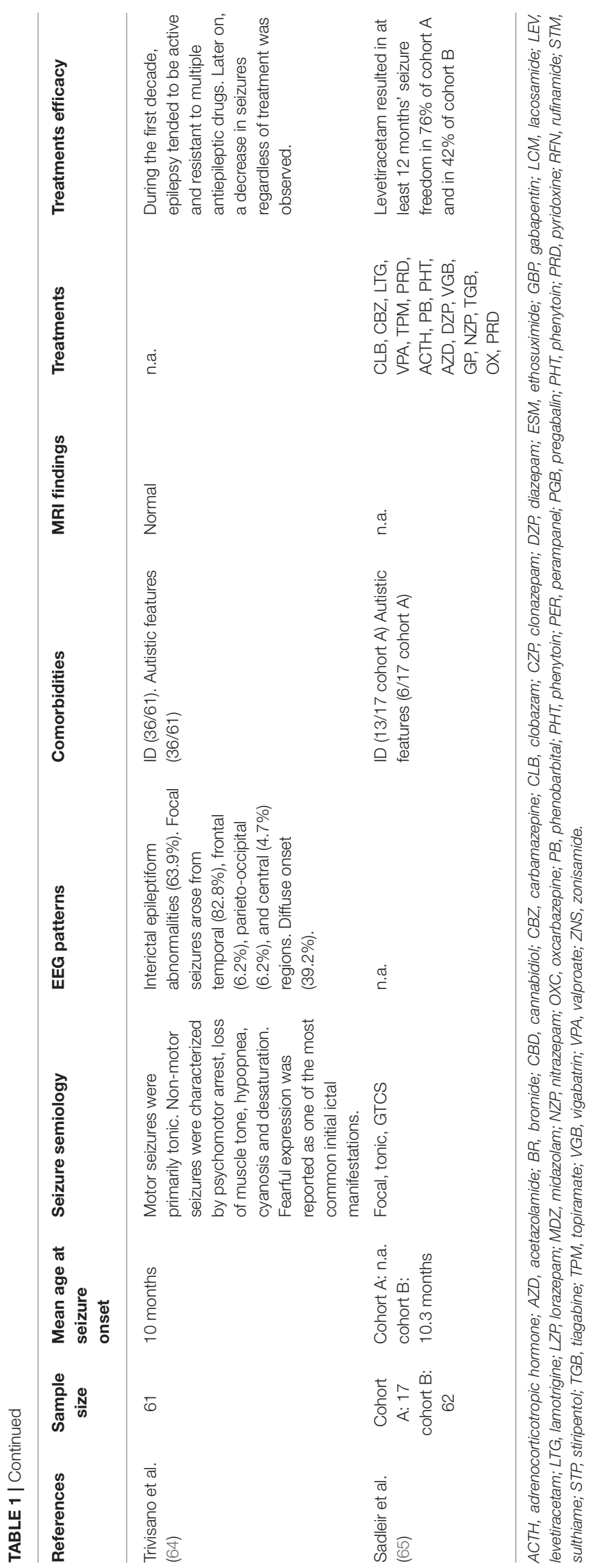

to antiseizure medication (ASM), therefore the pharmacological choice can be oriented in cases of affected patients in the same family (50). Despite DS, the use of sodium channel blockers such as lamotrigine and carbamazepine in PCDH-19-related epilepsy has shown less seizure exacerbation (22). Bromide and clobazam revealed higher efficacy in reducing seizures after 3 months of treatment with a partial reduction in effectiveness during long-term follow-up (63). Valproate and levetiracetam resulted among the most efficacious antiepileptic drugs with a response rate of 61 and 57\%, respectively after 12 months of use $(63,65)$. The effectiveness of phenytoin is unclear, Higurashi et al. showed a good response, not confirmed by Lotte et al. who reported a high grade of ineffectiveness and seizures worsening after phenytoin administration $(60,63)$. However, the small sample of patients treated with phenytoin in these studies raises doubts about the reliability of these results. Based on the similarities between DS and PCDH-19 related epilepsy, stiripentol was used in addition to valproate and clobazam in a female patient affected by PCDH19-related resistant epilepsy with a great efficacy (66). Stiripentol was later used, in six patients with PCDH-19 related epilepsy as an add-on to valproate and clobazam with a decrease of seizure frequency by more than $50 \%$ (56). It is not clear whether the efficacy obtained after stiripentol introduction was due to the intrinsic effect of the drug or to pharmacokinetic interactions causing an increase of clobazam and valproate blood levels $(56,66)$. PCDH19 gene mutation can be associated with reduced steroidogenesis. Confirming this hypothesis, Tan et al. identified dysregulated AKR1C1-3 which is involved in the production of allopregnanolone (67). Global decrease of neuroactive steroids such as allopregnanolone, pregnenolone sulfate, $17-\mathrm{OH}$ progesterone, and cortisol could be related to seizures onset in PCDH19 mutation. Thus, restoring steroidogenesis can be a therapeutic goal that may improve the management of this disorder (68). Although corticosteroids can be used to control seizure clusters, lacks a long-term benefit with a high risk of recurrences after interruption (22). Oral corticosteroid prophylaxis during febrile episodes was used in a Japanese study with no recurrence of moderate/severe clusters (57). The ketogenic diet showed a positive response in 50\% of patients. Vagus Nerve stimulation was used in only one case with a $75-90 \%$ seizure reduction at 3 months, persistent after 1 year (63). A single case report described an improvement in seizure control and development after leucovorin therapy in a patient with low cerebral folate levels (69). In conclusion, similarly to DS, GABAergic drugs are the most effective in the treatment of PCDH19-related epilepsy. In particular, first-line drugs that should be considered are bromide, clobazam, and valproate. Levetiracetam should be considered in patients with highly refractory clusters of seizures. Despite the predominance of focal seizures, carbamazepine does not appear as effective as expected, however sodium channel blockers showed relatively good effectiveness in some patients. Stiripentol may be effective especially in patients with DS-like, however, due to drug resistance, it is often necessary to use it in combination with clobazam and valproate. Aggravations of seizures were reported in connection with sodium channel blockers (58), with topiramate and valproate (60). The increasing number 
of antiseizure medications in the last decades has led to the development of new successful therapies. Recently, fenfluramine and cannabidiol have proved to be well tolerated and effective in reducing seizures frequency in DS $(70,71)$. Based on the existence of a similar therapeutic response between DS and PCDH19-related epilepsy, these therapies could be considered in the treatment of the latter patients. Seizure clusters are a frequent clinical manifestation of PCDH19-related epilepsy, especially in the early stages of the disease. Midazolam infusion has shown marked efficacy. However, a high risk of seizure recurrence and worsening during dose reduction or early withdrawal was reported (60). Intravenous phenytoin and phenobarbital were also used during seizure clusters with good responses (22). The risk of seizure recurrence after ASM withdrawal in PCDH19related epilepsy is significantly high. A recent study conducted on 42 patients with PCDH19-related epilepsy shows that $88.3 \%$ of ASM withdrawal leads to seizure recurrence. In $36.4 \%$ of cases, it was also necessary to increase the previous ASM dosage. Only in two cases, it was possible to totally withdraw ASM without seizure recurrence. Suspension of treatment was not only related to a high risk of seizure recurrence (72). Younger age and shorter previous seizure-free periods were risk factors for seizure recurrences, as reported from previous studies conducted on common epilepsies (73). Studies involving a wider population with PCDH19 mutation may improve the management and treatment of this disorder. Greater knowledge of gene variants and pathogenetic mechanisms underlying phenotypic expression could lead to a better understanding of the syndrome and a more effective pharmacological therapy.

\section{CONCLUSION}

The development of next-generation sequencing techniques has allowed us to bring the diagnosis to a deeper level recognizing specific gene variants and assessing any genotype-phenotype correlations. Besides SCN1A, PCDH19 is among the most

\section{REFERENCES}

1. Scheffer IE, Berkovic S, Capovilla G, Connolly MB, French J, Guilhoto L, et al. ILAE classification of the epilepsies: position paper of the ILAE Commission for Classification and Terminology. Epilepsia. (2017) 58:51221. doi: 10.1111/epi.13709

2. Symonds JD, McTague A. Epilepsy and developmental disorders: next generation sequencing in the clinic. Eur J Paediatr Neurol. (2020) 24:1523. doi: 10.1016/j.ejpn.2019.12.008

3. Kim SY, Mo JW, Han S, Choi SY, Han SB, Moon BH, et al. The expression of non-clustered protocadherins in adult rat hippocampal formation and the connecting brain regions. Neuroscience. (2010) 170:18999. doi: 10.1016/j.neuroscience.2010.05.027

4. Hulpiau P, van Roy F. Molecular evolution of the cadherin superfamily. Int J Biochem Cell Biol. (2009) 41:349-69. doi: 10.1016/j.biocel.2008. 09.027

5. Wu Q, Maniatis T. A striking organization of a large family of human neural cadherin-like cell adhesion genes. Cell. (1999) 97:77990. doi: 10.1016/s0092-8674(00)80789-8

6. Yagi T, Takeichi M. Cadherin superfamily genes: functions, genomic organization, and neurologic diversity. Genes Dev. (2000) 14:1169-80. relevant genes in epilepsy. The broad phenotypic spectrum of PCDH19-related epilepsy has been extensively studied in recent years and has led to improved and earlier recognition of symptoms. Further studies aimed at a better framing of the non-epileptic features and overall quality of life of these patients are needed. Especially cases of hemizygous males with psychiatric manifestations should be deeper investigated to better understand the expression of this gene and its peculiar inheritance pattern. Most mutations of PCDH19 occur in the extracellular domain, including whole and partial gene deletion and missense, nonsense, and frameshift mutation. The genotypephenotype correlation has been investigated in several studies; however, it is not yet known how different gene variants can alter clinical manifestations. Protocadherin-19 is known to have an essential role through its extracellular domain in cell adhesion and neuronal architecture (74). However, the role of this molecule is not limited to cell-cell interaction and involves important mechanisms of signal transmission through its intracellular domain. Thus, to optimize precision therapies with the aim of targeting underlying pathogenesis, it is essential to have a greater knowledge of the biological processes in which PCDH19 is involved and how these are altered by the mutations studied so far. In conclusion, it is important to consider PCDH19 in the context of genetic epilepsies. Molecular testing for PCDH19 mutations is recommended especially for female patients who present seizure clusters with early onset, with familiarity or characteristics compatible with GEFS+ or DS, and in cases with cognitive and psychiatric comorbidities.

\section{AUTHOR CONTRIBUTIONS}

GD and VV put forward the conception of the review and wrote the manuscript. AV and EM participated in the proposal of the concept and revised the manuscript. AF, GT, GD, and PS proposed suggestions for revision. All authors approved the submitted version.
7. Kolc KL, Sadleir LG, Scheffer IE, Ivancevic A, Roberts R, Pham DH, et al. A systematic review and meta-analysis of 271 PCDH19-variant individuals identifies psychiatric comorbidities, and association of seizure onset and disease severity. Mol Psychiatry. (2019) 24:241-51. doi: 10.1038/s41380-018-0066-9

8. Dibbens LM, Tarpey PS, Hynes K, Bayly MA, Scheffer IE, Smith R, et al. X-linked protocadherin 19 mutations cause female-limited epilepsy and cognitive impairment. Nat Genet. (2008) 40:776-81. doi: 10.1038/ng.149

9. Biswas S, Emond MR, Jontes JD. Protocadherin-19 and N-cadherin interact to control cell movements during anterior neurulation. J Cell Biol. (2010) 191:1029-41. doi: 10.1083/jcb.201007008

10. Gerosa L, Francolini M, Bassani S, Passafaro M. The role of protocadherin 19 (PCDH19) in neurodevelopment and in the pathophysiology of early infantile epileptic encephalopathy-9 (EIEE9). Dev Neurobiol. (2019) 79:7584. doi: 10.1002/dneu.22654

11. Borghi R, Magliocca V, Petrini S, Conti LA, Moreno S, Bertini E, et al. Dissecting the role of PCDH19 in clustering epilepsy by exploiting patient-specific models of neurogenesis. J Clin Med. (2021) 10:2754. doi: $10.3390 / j \mathrm{~cm} 10132754$

12. Mincheva-Tasheva S, Nieto Guil AF, Homan CC, Gecz J, Thomas PQ. Disrupted excitatory synaptic contacts and altered 
neuronal network activity underpins the neurological phenotype in PCDH19-clustering epilepsy (PCDH19-CE). Mol Neurobiol. (2021) 58:2005-18. doi: 10.1007/s12035-020-02242-4

13. Hoshina N, Johnson-Venkatesh EM, Hoshina M, Umemori H. Femalespecific synaptic dysfunction and cognitive impairment in a mouse model of PCDH19 disorder. Science. (2021) 372:eaaz3893. doi: 10.1126/science.aaz 3893

14. Bassani S, Cwetsch AW, Gerosa L, Serratto GM, Folci A, Hall IF, et al. The female epilepsy protein PCDH19 is a new GABAAR-binding partner that regulates GABAergic transmission as well as migration and morphological maturation of hippocampal neurons. Hum Mol Genet. (2018) 27:102738. doi: $10.1093 / \mathrm{hmg} / \mathrm{ddy} 019$

15. Serratto GM, Pizzi E, Murru L, Mazzoleni S, Pelucchi S, Marcello E, et al. The epilepsy-related protein PCDH19 regulates tonic inhibition, GABAAR kinetics, and the intrinsic excitability of hippocampal neurons. Mol Neurobiol. (2020) 57:5336-51. doi: 10.1007/s12035-020-02099-7

16. Higurashi N, Takahashi Y, Kashimada A, Sugawara Y, Sakuma H, Tomonoh $\mathrm{Y}$, et al. Immediate suppression of seizure clusters by corticosteroids in PCDH19 female epilepsy. Seizure. (2015) 27:1-5. doi: 10.1016/j.seizure.2015. 02.006

17. Juberg RC, Hellman CD, A. new familial form of convulsive disorder and mental retardation limited to females. J Pediatr. (1971) 79:72632. doi: $10.1016 / \mathrm{s} 0022-3476(71) 80382-7$

18. Scheffer IE, Turner SJ, Dibbens LM, Bayly MA, Friend K, Hodgson B, et al. Epilepsy and mental retardation limited to females: an under-recognized disorder. Brain. (2008) 131:918-27. doi: 10.1093/brain/awm338

19. Marini C, Darra F, Specchio N, Mei D, Terracciano A, Parmeggiani $\mathrm{L}$, et al. Focal seizures with affective symptoms are a major feature of PCDH19 gene-related epilepsy. Epilepsia. (2012) 53:2111-9. doi: 10.1111/j.1528-1167.2012.03649.x

20. Depienne C, Trouillard O, Bouteiller D, Gourfinkel-An I, Poirier K, Rivier F, et al. Mutations and deletions in PCDH19 account for various familial or isolated epilepsies in females. Hum Mutat. (2011) 32:E195975. doi: 10.1002/humu.21373

21. Camacho A, Simón R, Sanz R, Viñuela A, Martínez-Salio A, Mateos F. Cognitive and behavioral profile in females with epilepsy with PDCH19 mutation: two novel mutations and review of the literature. Epilepsy Behav. (2012) 24:134-7. doi: 10.1016/j.yebeh.2012.02.023

22. Samanta D. PCDH19-related epilepsy syndrome: a comprehensive clinical review. Pediatr Neurol. (2020) 105:39. doi: 10.1016/j.pediatrneurol.2019.10.009

23. Fabisiak K, Erickson RP. A familial form of convulsive disorder with or without mental retardation limited to females: extension of a pedigree limits possible genetic mechanisms. Clin Genet. (1990) 38:353-8. doi: 10.1111/j.1399-0004.1990.tb03594.x

24. Depienne C, Bouteiller D, Keren B, Cheuret E, Poirier K, Trouillard O, et al. Sporadic infantile epileptic encephalopathy caused by mutations in PCDH19 resembles Dravet syndrome but mainly affects females. PLoS Genet. (2009) 5:e1000381. doi: 10.1371/journal.pgen.1000381

25. Kolc KL, Møller RS, Sadleir LG, Scheffer IE, Kumar R, Gecz J. PCDH19 pathogenic variants in males: expanding the phenotypic spectrum. Adv Exp Med Biol. (2020) 1298:177-87. doi: 10.1007/5584_2020_574

26. Smith L, Singhal N, El Achkar CM, Truglio G, Rosen Sheidley B, Sullivan J, et al. PCDH19-related epilepsy is associated with a broad neurodevelopmental spectrum. Epilepsia. (2018) 59:679-89. doi: 10.1111/epi.14003

27. Shibata M, Ishii A, Goto A, Hirose S. Comparative characterization of PCDH19 missense and truncating variants in PCDH19-related epilepsy. $J$ Hum Genet. (2021) 66:569-78. doi: 10.1038/s10038-020-00880-z

28. Kolc KL, Sadleir LG, Depienne C, Marini C, Scheffer IE, Møller RS, et al. A standardized patient-centered characterization of the phenotypic spectrum of PCDH19 girls clustering epilepsy. Transl Psychiatry. (2020) 10:127. doi: 10.1038/s41398-020-0803-0

29. Scheffer IE, Berkovic SF. Generalized epilepsy with febrile seizures plus. A genetic disorder with heterogeneous clinical phenotypes. Brain. (1997) 120:479-90. doi: 10.1093/brain/120.3.479

30. Zhang YH, Burgess R, Malone JP, Glubb GC, Helbig KL, Vadlamudi L, et al. Genetic epilepsy with febrile seizures plus: Refining the spectrum. Neurology. (2017) 89:1210-9. doi: 10.1212/WNL.0000000000004384
31. Myers KA, Scheffer IE, Berkovic SF, ILAE Genetics Commission. Genetic literacy series: genetic epilepsy with febrile seizures plus. Epileptic Disord. (2018) 20:232-8. doi: 10.1684/epd.2018.0985

32. Baulac S, Gourfinkel-An I, Picard F, Rosenberg-Bourgin M, Prud'homme JF, Baulac M, et al. A second locus for familial generalized epilepsy with febrile seizures plus maps to chromosome 2q21-q33. Am J Hum Genet. (1999) 65:1078-85. doi: $10.1086 / 302593$

33. Singh R, Scheffer IE, Crossland K, Berkovic SF. Generalized epilepsy with febrile seizures plus: a common childhood-onset genetic epilepsy syndrome. Ann Neurol. (1999) 45:75-81. doi: 10.1002/1531-8249(199901)45:1<75::aid$\operatorname{art13}>3.0 . c 0 ; 2-\mathrm{w}$

34. Wallace RH, Wang DW, Singh R, Scheffer IE, George AL Jr, Phillips HA, et al. Febrile seizures and generalized epilepsy associated with a mutation in the Na+-channel betal subunit gene SCN1B. Nat Genet. (1998) 19:36670. doi: $10.1038 / 1252$

35. Eckhaus J, Lawrence KM, Helbig I, Bui M, Vadlamudi L, Hopper JL, et al. Genetics of febrile seizure subtypes and syndromes: a twin study. Epilepsy Res. (2013) 105:103-9. doi: 10.1016/j.eplepsyres.2013.02.011

36. Myers KA, Burgess R, Afawi Z, Damiano JA, Berkovic SF, Hildebrand MS, et al. De novo SCN1A pathogenic variants in the GEFS+ spectrum: not always a familial syndrome. Epilepsia. (2017) 58:e26-30. doi: 10.1111/epi.13649

37. Marini C, Mei D, Temudo T, Ferrari AR, Buti D, Dravet C, et al. Idiopathic epilepsies with seizures precipitated by fever and SCN1A abnormalities. Epilepsia. (2007) 48:1678-85. doi: 10.1111/j.1528-1167.2007.01122.x

38. Baulac S, Huberfeld G, Gourfinkel-An I, Mitropoulou G, Beranger A, Prud'homme JF, et al. First genetic evidence of GABA(A) receptor dysfunction in epilepsy: a mutation in the gamma2-subunit gene. Nat Genet. (2001) 28:46-8. doi: 10.1038/ng0501-46

39. Wallace RH, Scheffer IE, Barnett S, Richards M, Dibbens L, Desai RR, et al. Neuronal sodium-channel alpha1-subunit mutations in generalized epilepsy with febrile seizures plus. Am J Hum Genet. (2001) 68:85965. doi: $10.1086 / 319516$

40. Tian M, Mei D, Freri E, Hernandez CC, Granata T, Shen W, et al. Impaired surface $\alpha \beta \gamma$ GABA(A) receptor expression in familial epilepsy due to a GABRG2 frameshift mutation. Neurobiol Dis. (2013) 50:13541. doi: 10.1016/j.nbd.2012.10.008

41. Ishii A, Kanaumi T, Sohda M, Misumi Y, Zhang B, Kakinuma N, et al. Association of nonsense mutation in GABRG2 with abnormal trafficking of GABAA receptors in severe epilepsy. Epilepsy Res. (2014) 108:42032. doi: 10.1016/j.eplepsyres.2013.12.005

42. Marini C, Harkin LA, Wallace RH, Mulley JC, Scheffer IE, Berkovic SF. Childhood absence epilepsy and febrile seizures: a family with a GABA(A) receptor mutation. Brain. (2003) 126:230-40. doi: 10.1093/brain/awg018

43. Schubert J, Siekierska A, Langlois M, May P, Huneau C, Becker F, et al. Mutations in STX1B, encoding a presynaptic protein, cause fever-associated epilepsy syndromes. Nat Genet. (2014) 46:1327-32. doi: 10.1038/ng.3130

44. Singh NA, Pappas C, Dahle EJ, Claes LR, Pruess TH, De Jonghe P, et al. A role of SCN9A in human epilepsies, as a cause of febrile seizures and as a potential modifier of Dravet syndrome. PLoS Genet. (2009) 5:e1000649. doi: 10.1371/journal.pgen.1000649

45. Mulley JC, Hodgson B, McMahon JM, Iona X, Bellows S, Mullen SA, et al. Role of the sodium channel SCN9A in genetic epilepsy with febrile seizures plus and Dravet syndrome. Epilepsia. (2013) 54:e122-6. doi: 10.1111/epi.12323

46. Dibbens LM, Feng HJ, Richards MC, Harkin LA, Hodgson BL, Scott D, et al. GABRD encoding a protein for extra- or peri-synaptic GABAA receptors is a susceptibility locus for generalized epilepsies. Hum Mol Genet. (2004) 13:1315-9. doi: 10.1093/hmg/ddh146

47. Puranam RS, He XP, Yao L, Le T, Jang $W$, Rehder CW, et al. Disruption of Fgf13 causes synaptic excitatory-inhibitory imbalance and genetic epilepsy and febrile seizures plus. J Neurosci. (2015) 35:886681. doi: 10.1523/JNEUROSCI.3470-14.2015

48. Rigbye KA, van Hasselt PM, Burgess R, Damiano JA, Mullen SA, Petrovski $\mathrm{S}$, et al. Is FGF13 a major contributor to genetic epilepsy with febrile seizures plus? Epilepsy Res. (2016) 128:48-51. doi: 10.1016/j.eplepsyres.2016.10.008

49. Specchio N, Marini C, Terracciano A, Mei D, Trivisano M, Sicca F, et al. Spectrum of phenotypes in female patients with epilepsy due to protocadherin 19 mutations. Epilepsia. (2011) 52:1251-7. doi: 10.1111/j.1528-1167.2011.03063.x 
50. Yang L, Liu J, Su Q, Li Y, Yang X, Xu L, et al. Novel and de novo mutation of PCDH19 in girls clustering epilepsy. Brain Behav. (2019) 9:e01455. doi: 10.1002/brb3.1455

51. Dravet C. The core Dravet syndrome phenotype. Epilepsia. (2011) 52:39. doi: 10.1111/j.1528-1167.2011.02994.x

52. Claes L, Del-Favero J, Ceulemans B, Lagae L, Van Broeckhoven C, De Jonghe $\mathrm{P}$, et al. novo mutations in the sodium-channel gene SCN1A cause severe myoclonic epilepsy of infancy. Am J Hum Genet. (2001) 68:132732. doi: 10.1086/320609

53. Steel D, Symonds JD, Zuberi SM, Brunklaus A. Dravet syndrome and its mimics: Beyond SCN1A. Epilepsia. (2017) 58:1807-16. doi: 10.1111/epi. 13889

54. Kwong AK, Fung CW, Chan SY, Wong VC. Identification of SCN1A and PCDH19 mutations in Chinese children with Dravet syndrome. PLoS ONE. (2012) 7:e41802. doi: 10.1371/journal.pone.0041802

55. Rampazzo ACM, Dos Santos RRP, Maluf FA, Simm RF, Marson FAL, Ortega MM, et al. Dravet syndrome and Dravet syndrome-like phenotype: a systematic review of the SCN1A and PCDH19 variants. Neurogenetics. (2021) 22:105-15. doi: 10.1007/s10048-021-00644-7

56. Chemaly N, Losito E, Pinard JM, Gautier A, Villeneuve N, Arbues AS, et al. Early and long-term electroclinical features of patients with epilepsy and PCDH19 mutation. Epileptic Disord. (2018) 20:457-67. doi: 10.1684/epd.2018.1009

57. Trivisano M, Pietrafusa N, Ciommo Vd, Cappelletti S, Palma Ld, Terracciano A, et al. PCDH19-related epilepsy and Dravet Syndrome: face-off between two early-onset epilepsies with fever sensitivity. Epilepsy Res. (2016) 125:326. doi: 10.1016/j.eplepsyres.2016.05.015

58. Fattorusso A, Matricardi S, Mencaroni E, Dell'Isola GB, Di Cara G, Striano P, et al. The pharmacoresistant epilepsy: an overview on existant and new emerging therapies. Front Neurol. (2021) 12:674483. doi: 10.3389/fneur.2021.674483

59. Marini C, Mei D, Parmeggiani L, Norci V, Calado E, Ferrari A, et al. Protocadherin 19 mutations in girls with infantile-onset epilepsy. Neurology. (2010) 75:646-53. doi: 10.1212/WNL.0b013e3181ed9e67

60. Higurashi N, Nakamura M, Sugai M, Ohfu M, Sakauchi M, Sugawara Y, et al. PCDH19-related female-limited epilepsy: further details regarding early clinical features and therapeutic efficacy. Epilepsy Res. (2013) 106:1919. doi: 10.1016/j.eplepsyres.2013.04.005

61. van Harssel JJ, Weckhuysen S, van Kempen MJ, Hardies K, Verbeek NE, de Kovel CG, et al. Clinical and genetic aspects of PCDH19related epilepsy syndromes and the possible role of PCDH19 mutations in males with autism spectrum disorders. Neurogenetics. (2013) 14:2334. doi: 10.1007/s10048-013-0353-1

62. Liu A, Xu X, Yang X, Jiang Y, Yang Z, Liu X, et al. The clinical spectrum of female epilepsy patients with PCDH19 mutations in a Chinese population. Clin Genet. (2017) 91:54-62. doi: 10.1111/cge.12846

63. Lotte J, Bast T, Borusiak P, Coppola A, Cross JH, Dimova P, et al. Effectiveness of antiepileptic therapy in patients with PCDH19 mutations. Seizure. (2016) 35:106-10. doi: 10.1016/j.seizure.2016.01.006

64. Trivisano M, Pietrafusa N, Terracciano A, Marini C, Mei D, Darra F, et al. Defining the electroclinical phenotype and outcome of PCDH19-related epilepsy: a multicenter study. Epilepsia. (2018) 59:2260-71. doi: 10.1111/epi.14600
65. Sadleir LG, Kolc KL, King C, Mefford HC, Dale RC, Gecz J, et al. Levetiracetam efficacy in PCDH19 girls clustering epilepsy. Eur J Paediatr Neurol. (2020) 24:142-7. doi: 10.1016/j.ejpn.2019.12.020

66. Trivisano M, Specchio N, Vigevano F. Extending the use of stiripentol to other epileptic syndromes: a case of PCDH19-related epilepsy. Eur J Paediatr Neurol. (2015) 19:248-50. doi: 10.1016/j.ejpn.2014.11.008

67. Tan C, Shard C, Ranieri E, Hynes K, Pham DH, Leach D, et al. Mutations of protocadherin 19 in female epilepsy (PCDH19-FE) lead to allopregnanolone deficiency. Hum Mol Genet. (2015) 24:5250-9. doi: 10.1093/hmg/ddv245

68. Trivisano M, Lucchi C, Rustichelli C, Terracciano A, Cusmai R, Ubertini GM, et al. Reduced steroidogenesis in patients with PCDH19-female limited epilepsy. Epilepsia. (2017) 58:e91-5. doi: 10.1111/epi.13772

69. Renaud DL. Treatment of low cerebrospinal fluid 5-methyltetrahydrofolate with leucovorin improves seizure control and development in PCDH19-related epilepsy. Pediatr Neurol. (2021) 114:910. doi: 10.1016/j.pediatrneurol.2020.08.019

70. Lagae L, Sullivan J, Knupp K, Laux L, Polster T, Nikanorova M, et al. Fenfluramine hydrochloride for the treatment of seizures in Dravet syndrome: a randomised, double-blind, placebo-controlled trial. Lancet. (2019) 394:2243-54. doi: 10.1016/S0140-6736(19)32500-0

71. Devinsky O, Cross JH, Laux L, Marsh E, Miller I, Nabbout R, et al. Cannabidiol in Dravet Syndrome Study Group. Trial of cannabidiol for drugresistant seizures in the Dravet syndrome. N Engl J Med. (2017) 376:201120. doi: 10.1056/NEJMoa1611618

72. Aledo-Serrano Á, Del Ser T, Gil-Nagel A. Antiseizure medication withdrawal in seizure-free patients with PCDH19-related epilepsy: a multinational cohort survey. Seizure. (2020) 80:259-61. doi: 10.1016/j.seizure.2020.06.007

73. Lamberink HJ, Otte WM, Geerts AT, Pavlovic M, Ramos-Lizana J, Marson AG, et al. Individualised prediction model of seizure recurrence and longterm outcomes after withdrawal of antiepileptic drugs in seizure-free patients: a systematic review and individual participant data meta-analysis. Lancet Neurol. (2017) 16:523-31. doi: 10.1016/S1474-4422(17)30114-X

74. Redies C, Hertel N, Hübner C. Cadherins and neuropsychiatric disorders. Brain Res. (2012) 1470:130-44. doi: 10.1016/j.brainres.2012.06.020

Conflict of Interest: The authors declare that the research was conducted in the absence of any commercial or financial relationships that could be construed as a potential conflict of interest.

Publisher's Note: All claims expressed in this article are solely those of the authors and do not necessarily represent those of their affiliated organizations, or those of the publisher, the editors and the reviewers. Any product that may be evaluated in this article, or claim that may be made by its manufacturer, is not guaranteed or endorsed by the publisher.

Copyright (C) 2022 Dell'Isola, Vinti, Fattorusso, Tascini, Mencaroni, Di Cara, Striano and Verrotti. This is an open-access article distributed under the terms of the Creative Commons Attribution License (CC BY). The use, distribution or reproduction in other forums is permitted, provided the original author(s) and the copyright owner(s) are credited and that the original publication in this journal is cited, in accordance with accepted academic practice. No use, distribution or reproduction is permitted which does not comply with these terms. 